\title{
EFFECT OF OZONE APPLICATION ON POSTHARVEST QUALITY AND MICROBIOLOGICAL STATE OF "ZAGHLOUL" DATE PALM FRUITS
}

\author{
Hoda A. Khalil
}

Department of Pomology, Faculty of Agriculture, Alexandria University, Aflaton street, 21545-El Shatby, Alexandria, Egypt

Email address: hodaagri@hotmail.com, hoda.khalil@alexu.edu.eg

\begin{abstract}
The postharvest quality of 'Zaghloul' date palm cultivar was investigated to study the effects of ozone on weight loss rate, electrolyte leakage (EL), total soluble solids (TSS), titratable acidity (TA), ascorbic acid, total phenol content and antioxidant activity at harvest and during cold storage at $0 \pm 1^{\circ} \mathrm{C}$ for up to 30 days. Moreover, the study aimed to elucidate the efficiency of ozone application on controlling microbial growth. The fruits were exposed to $150 \mathrm{ppb}$ ozone $\left(\mathrm{O}_{3}\right)$ by using ozone generator (biofresh OZ80, UK).The results indicated that ozone application reduced the yeasts and molds and mesophilic aerobic bacteria compared to control. Ozone treated fruits had higher weight loss than control but the differences were not significant. However, Ozone treated fruit showed lower total soluble solid, electrolyte leakage, and rutab\% compared to non-ozone treated ones. Ozone treated fruits had higher ascorbic acid and total phenol contents as well as antioxidant activity, while did not significantly affect fruit titratable acidity. Thus, ozone application could be an effective strategy for maintaining post-harvest quality of dates and provide a longer storage life.
\end{abstract}

\section{INTRODUCTION}

Date is one of the most popular fruits consumed in Egypt for its high nutritional value and favorable taste. The date palm fruits (Phoenix dactylifera L.) are highly demanded and consumed throughout the world, especially in the Middle East. According to FAO, 2009, dates are stored under refrigeration for months to supply both national and international markets. Unfortunately, storage of fresh crops is accompanied by water evaporation, respiration, physiological changes, insects attack and microbial spoilage which could causes heavy losses reaching up to $40 \%$ in the developing countries, which are considered the most date fruits producers (FAO, 2009). Methyl bromide is the most widely used pesticide for harvested date palm in developing countries but, because of its toxicity to applicators and to the environment, its use forbidden since 2015 ( Bell, 2000 and UNEP, 1995). In recent years, the concern about public health and the environment has considerably limited the use of fungicides after harvest and consumer demand for fungicide-free fruit has led to increasing interested to find alternative approaches in order to control postharvest diseases and keeping quality of the fruits.

Ozone is triatomic oxygen $\left(\mathrm{O}_{3}\right)$ and is wellknown as a strong oxidizing agent that has been used for post-harvest disease control and other storage uses for many years. Since 2001 it was listed as a secondary food additive permitted in food for human consumption (FDA, 2009). It oxidizes microorganisms' cell membranes, nucleic acid and intracellular enzymes, hence inhibits their growth and fruits tissue attack (Khadre et al., 2001). This has been demonstrated on a variety of crops such as peach (Palou et al., 2002), orange (Palou et al. 2003), kiwi (Minas et al. 2010) and table grapes (Ozkan et al., 2011 and Yaseen et al., 2014). In comparison to synthetic fungicides, ozone decomposes to oxygen without leaving residues on fruit. Ozone has been evaluated as a sanitizer in the food industry aiming to inactive bacterial growth (Sharma et al., 2002), prevent fungal decay (Palou et al., 2002 and Pérez et al., 1999), destruct pesticides and chemical residues (Hwang et al., 2001), as well as extend postharvest life of horticultural products through the ozone-mediated oxidation of ethylene (Skog and Chu, 2001). However, due to its strong oxidizing activity, ozone may affect the physiology of the fruit and consequently influences to the fruit physiochemical qualities. When $\mathrm{O}_{3}$ enters fresh fruit tissue, it may induce oxidative stress resulting in various physiological responses, including synthesis of antioxidants, polyamines, ethylene, phenolic compounds, and other secondary metabolites (Forney 2003) and the quality of fruits is affected. Many studies have focused on the influence of ozone-enriched environment on fruit microbial attack, while reports aiming to elucidate the effect of ozone on fruit quality are limited. With regard to dates, there are scarce published reports on the efficacy of ozone treatments in post-harvest diseases control and fruit quality. Therefore, the present study was conducted in order to evaluate the effectiveness of ozone in controlling microbial contamination of dates. In relation to the importance of antioxidant compounds in date fruits, the objectives of this research aimed also to study the effect of ozone on fruit quality parameters such antioxidant activity, total phenolic (TP) and total soluble solids contents.

\section{MATERIALS AND METHODS}

\section{Plant materials and experimental procedure}

The present study was carried out during 2014 and 2015 seasons on date palm fruits of 'Zaghloul' cv., (Phoenix dactylifera L.). Date bunches were hand harvested at the end of November at full maturity ('Khalal' stage) from a private farm located in Mariot region $\left(30^{\circ} 55^{\prime} 33.34^{\prime \prime} \mathrm{N}\right.$ and $\left.29^{\circ} 46^{\prime} 31.81^{\prime \prime} \mathrm{E}\right)$ at Alexandria Desert Road, Egypt. Bunches were detached from the head of the tree palm then cut into strands and carefully selected. Strands were placed in polyethylene 
bags and transported immediately to the post-harvest handling laboratory of the Faculty of Agriculture, Alexandria University, Egypt. After arriving to the lab, fruits were manually detached from the strands and fruits that are uniform in size and free of mechanical damage were selected. In a disinfected area at room temperature, fruits were divided into two groups (500 fruits for each), each group divided into 4 subgroups as replicates (replicate $=125$ fruits). Both groups were stored in cold storage room for up to 15 and 30 days at 0 $\pm 1{ }^{\circ} \mathrm{C}$ and $95 \% \mathrm{RH}$, one group was left without ozone treatment (control) and the other fruit group was continuously exposed to air enriched with $150 \mathrm{ppb}$ of ozone up to 30 days (end of experiment). An ozone generator (biofresh OZ80, UK) was used to achieve the desired concentration. Ozone dose was selected according to results reached in preliminary experiment (El-Saedy et al., 2011).

\section{Microbial contamination}

To determine microbial growth, two randomized samples of 40 fruits from each fruit group (ozonated and non-ozonated fruits) treatment were taken at the handling day (Before exposed to ozone gas) and after 30 days. By gloves fruits were transferred to sterile plastic bags containing $30 \mathrm{ml}$ of $0.1 \%$ buffered peptone water (BPW). Bags were hand- rubbed for a minute to remove surface microorganisms (Parish et al., 2003). Colonize number of Mesophilic aerobic bacteria and yeasts and molds, was counted according to the methods of Beuchat and Cousin (2001) and Morton (2001). Data were recorded as colony forming units per gram (CFU/g).

\section{Physicochemical parameters}

At handling day and after 15 and 30 days of cold storage, physical and chemical parameters of dates were evaluated by determine weight loss $(\%)$, electrolyte leakage according to Salvador et al (2006), titratable acidity (measured by titration with $0.1 \mathrm{~N} \mathrm{NaOH}$ according to AOAC, 1995, total soluble solids (measured as \% by a hand refractometer, ATC-1E, Atago, Japan), percentage of fruit rutab (visually estimated as fruit showing softening more than $10 \%$ of its total area), Ascorbic acids determined using 2, 6 Dichlrophenol indophenols for the titration of juice and presented as mg/100 $\mathrm{g}$ fresh weight (Ranganna, 1979).

For the estimation of total phenols content a quantity of $5 \mathrm{~g}$ of fruit tissue was homogenized in $15 \mathrm{ml}$ ethanol $95 \%$ and boiled for 15 minutes. The homogenate was filtrated through Whatman No.1filter paper (Whatman Laboratory Division, Springfield Mill, England). A quantity of $0.5 \mathrm{ml}$ Folin-Denis reagent was added to $1 \mathrm{ml}$ of the alcoholic extract and after 5 minutes, $7 \mathrm{ml}$ saturated sodium carbonate solution was added, shaken and left for 0.5 hours. Optical density was measured at $750 \mathrm{~nm}$ and total phenols were calculated from a standard curve of gallic acid. These data were expressed as the mg gallic acid equivalents per gram of fresh weight basis according to Cheng and Hanning (1955).

Regarding valuation of antioxidants activity, it was measured according to the method described by Ao et al., (2008). Two grams of khalal fruit tissues was extracted by shaking at $150 \mathrm{rpm}$ for $24 \mathrm{~h}$ with $20 \mathrm{ml}$ methanol $(80 \%)$ and filtrated through Whatman No. 1 filter paper. About $0.1 \mathrm{ml}$ of methanol extract was mixed with $0.9 \mathrm{ml}$ of freshly prepared DPPH $(1,1$ diphenyl-2-picrylhydrazyl) methanol solution $(0.1 \mathrm{mM})$. An equal amount of methanol was used as a control. After $30 \mathrm{~min}$ of incubation at room temperature at the dark, the optical density (OD) was measured at $517 \mathrm{~nm}$ using a spectrophotometer. The percentage of DPPH radical scaving percentage, in the steady state, was calculated as follows: [(OD control- OD sample) / OD control]. The $\mathrm{IC}_{50}$ value is the inhibition concentration as $\mu \mathrm{g}$ phenol of the test sample that decreases $50 \%$ of initial radical scavenging. The $\mathrm{IC}_{50}$ values were calculated from the calibration curve. Analyses were performed on the handling day and after 15 and 30 days of storage at $(0 \pm 1){ }^{\circ} \mathrm{C}$ and $90-95 \%$.

\section{Statistical analysis}

All data were tested for treatments effects on analyzed parameters by the one-way analysis of variance (ANOVA) technique. Treatments means were separated and compared using the LSD test at 0.05 level of significance according to the method described by Snedecor and Cochran (1980). The statistical analysis was performed using CoStat software package for Windows.

\section{RESULTS AND DISCUSSION}

\section{Effect of ozone on microbiological quality}

Table 1 presented the microbial load at handling date and after 30 days of cold storage. As expected, microbial counts increased with storage time. The levels of contamination of control samples were increased during cold storage from $4.9 \times 10^{2}$ to $4.5 \times 10^{3}$ for yeasts and molds and from $2.9 \times 10^{4}$ to $7.7 \times 10^{4}$ for the total mesophilic aerobic bacteria in both years. Ozone treatment reduced the level of microorganisms load compared to control. At the end of the storage period, yeasts and molds were not detected and total mesophilic aerobic bacteria count with ozone treatment reduced from $3.4 \times 10^{4}$ to $5.2 \times 10^{2}$ in 2014 and from $6.5 \times 10^{3}$ to $8.5 \times 10^{2}$ in 2015 . These results confirm those previously reported by Najafi and Khodaparast (2009), who found that a one hour ozone treatment at $5 \mathrm{ppm}$ could be successfully used for reducing coliforms and $S$. aureus of date fruits, but longer exposure times are required for elimination of the total mesophilic bacteria as well as yeasts/molds. In addition, Aleid and Hamad (2014) reported that treating date palm fruits with ozonated water reduced contamination with mesophillic aerobic bacteria, yeasts and molds. Antimicrobial efficacy of ozone has been studied for many microorganisms, including vegetative bacteria, bacterial spores, virus, yeasts, and molds. The mechanism of microbicidal action of ozone is a complex process, because ozone attacks numerous cellular constituents including proteins, unsaturated lipids and respiratory enzymes in cell membranes, peptidoglycans in cell envelopes, enzymes and nucleic acids in the cytoplasm, and 
proteins and peptidoglycan in spore coats and virus capsids (Khadre, 2001). Moreover, Komanapalli and Lau (1996) demonstrated that the inactivation of vegetative bacteria by ozone is achieved by the progressive oxidation of vital cellular components. It has been suggested that cell surface is the primary target of ozonation, occurring degradation of unsaturated lipids of the cell envelope. When a large part of the membrane barrier is destroyed, disruption of the cell occurs with subsequent leakage of cellular contents and bacterial cells lyses. When this is not sufficient for the immediate cell destruction, ozone can penetrate inside the bacterium and oxidize certain essential components, e.g., proteins, enzymes, and nucleic acids. Similarly, Freitas-Silva and Venancio (2010) suggested that the mechanism involved in fungi inactivation by ozone is also related with implications in membrane integrity.

Table1. The effect of ozone exposure on yeasts and molds and total mesophilic aerobic bacteria counts (mean $\log \mathrm{CFU} \mathrm{\textrm {g } ^ { - 1 }}$ ) of Zaghloul date fruits after 30 days of cold storage at $\mathrm{0} \pm 1^{\circ} \mathrm{C}$ in 2014 and 2015 seasons

\begin{tabular}{|l|c|c|c|c|}
\hline \multirow{2}{*}{ Treatments } & \multicolumn{3}{|c|}{ Yeasts and molds (cfu/gm) } & \multicolumn{2}{c|}{ Mesophilic aerobic bacteria } \\
\cline { 2 - 5 } & Handling day & After 30 days & After 30 days \\
\cline { 2 - 5 } & \multicolumn{4}{|c|}{2014} \\
\hline Control & $4.9 \times 10^{2} \mathrm{a}$ & $4.5 \times 10^{3}$ & $2.9 \times 10^{4} \mathrm{a}$ & $7.7 \times 10^{4} \mathrm{a}$ \\
\hline Ozone & $4.5 \times 10^{2} \mathrm{a}$ & $\mathrm{n} . \mathrm{d}$ & $3.4 \times 10^{4} \mathrm{a}$ & $5.2 \times 10^{2} \mathrm{~b}$ \\
\hline \multicolumn{5}{|c|}{} \\
\hline Control & $1.0 \times 10^{2} \mathrm{a}$ & 2015 & $7.0 \times 10^{3} \mathrm{a}$ & $9.0 \times 10^{3} \mathrm{a}$ \\
\hline Ozone & $1.8 \times 10^{2} \mathrm{a}$ & $\mathrm{n} . \mathrm{n} \times 10^{2}$ & $6.5 \times 10^{3} \mathrm{a}$ & $8.5 \times 10^{2} \mathrm{~b}$ \\
\hline
\end{tabular}

Control: without ozone

Means in a column followed by a different letter differ significantly at $P=0.05$ by $L . S . D$ test.

\section{Effect of ozone on physicochemical parameters Fruit weight loss}

Data of both 2014 and 2015 seasons (Fig. 1a) showed that fruit weight loss did not significantly differ between ozone treated fruits and non-ozone treated fruits (control) and stored for 15 and 30 days. In general, weight loss increased with extending storage period. Similar to the obtained results, Palou et al., 2002 found that no significant differences in fruit weight loss between ozone and control treatments in 'Flame Seedless' grapes. In contrast Palou et al. (2002) reported that the exposure of 'Zee lady' peaches to $0.3 \mathrm{ppm}$ gaseous ozone caused a reduction of fruit weight. They concluded that cuticle and/or the epidermal fruit tissues could be damaged during ozone exposure. On the other hand, Zhang et al. (2011) found that gaseous ozone reduced weight loss rate of strawberries and this reduction related to a better maintenance of fruit firmness.

\section{Electrolyte leakage}

Results of 2014 and 2015 (Fig. 1b) showed that generally fruit electrolyte leakage percent increased with extending storage period. Also the obtained data revealed that non-ozone treated fruits indicated higher leakage than ozone treated fruits after 15 and 30 days of cold storage. The results of electrolyte leakage from fruit tissues coincided with the results of the rutab percentages. As more rutab development is obtained more electrolyte leakage is expected. Rao et al., (2000) reported that ozone can react with lipids, proteins and cuticular components in plants resulted in membrane lipids damage. Moreover, Liew and Prange (1994) observed physiological disruptions symptoms, such as color changes, electrolyte leakage and respiration rate with ozone residual concentration of 10 to $22 \mu \mathrm{L} \mathrm{L}^{-1}$ at $2^{\circ} \mathrm{C}$. In broccoli, ozone treatment $\left(1.7 \mu \mathrm{LL}^{-1}\right)$ caused a loss of cellular compartimentation and an increase of membrane permeability (Skog and Chu, 2001).

\section{Fruit rutab percentage}

Results presented in Fig. 1c showed that fruit rutab percent did not differ significantly between ozone treated fruits and non-treated ones after 15 days of cold storage. However, after 30 days non-ozone treated fruits showed a significantly higher rutab percent than ozone treated ones. Ethylene is known as the major trigger and coordinator of the ripening process. (Abeles et al., 1992). Ozone delayed climacteric ethylene rise and totally blocked ethylene production during intermediate and long cold storage. Once ethylene plays an important role in produce senescence, these results revealed that ozone can be a main key on the ripening process delay of some fruits and vegetables. Zaghloul date palms might follow an ethylene-independent ripening process and its ripening process is not regulated by ethylene. Therefore the rutab percentage retained at lower levels by ozone might be due to the higher $\mathrm{CO}_{2}$ concentration, reducing respiration, later senescence and slower ripening leading to increase rutabe percentage. This is in agreement with the study of Toivonen and Stan (2004), in which it is described that ozonation reduces respiration, once samples washed in water containing ozone have lower respiration than the ones that have not been treated. In addition, Liew and Prange (1994) found a slight increase in $\mathrm{CO}_{2}$ production in carrots. Zhang et al. (2005) reported no significant differences between respiration rate of fresh-cut celery treated with $0.03 \mathrm{ppm}$ of ozonated water and non-treated samples during storage. However, respiration rate was inhibited by treatment with water containing ozone at 0.08 and 0.18 ppm. They suggested that the efficacy of respiration rate inhibition increased with the increase in ozone concentration in water, showing that ozone was able to retard tissue metabolism. 

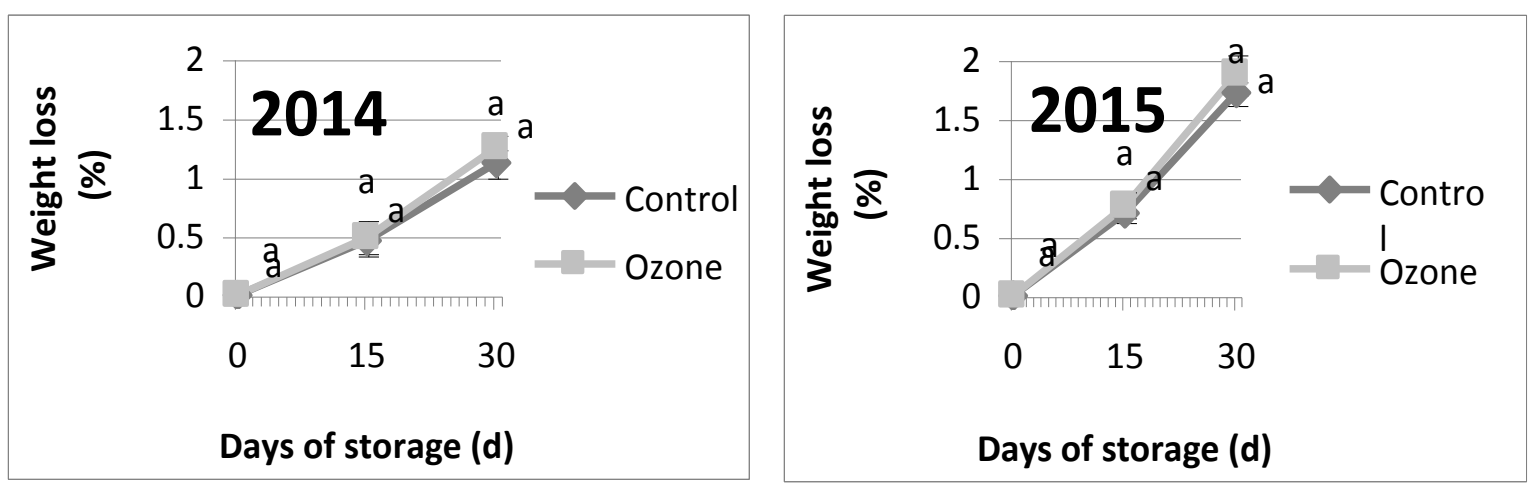

(a)
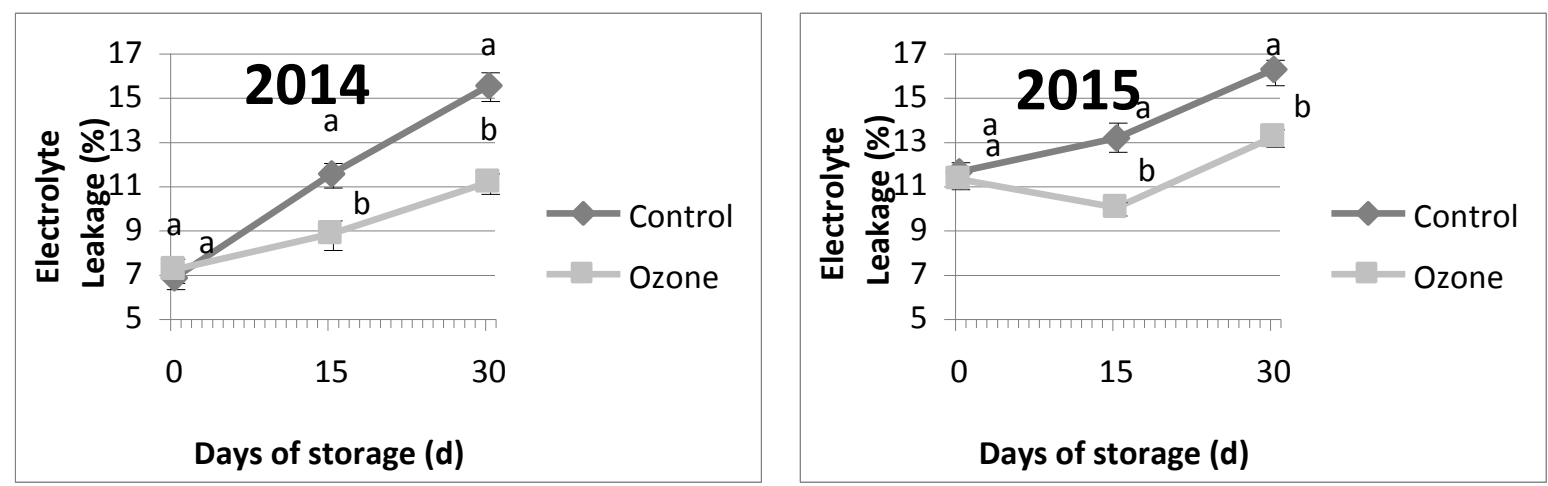

(b)
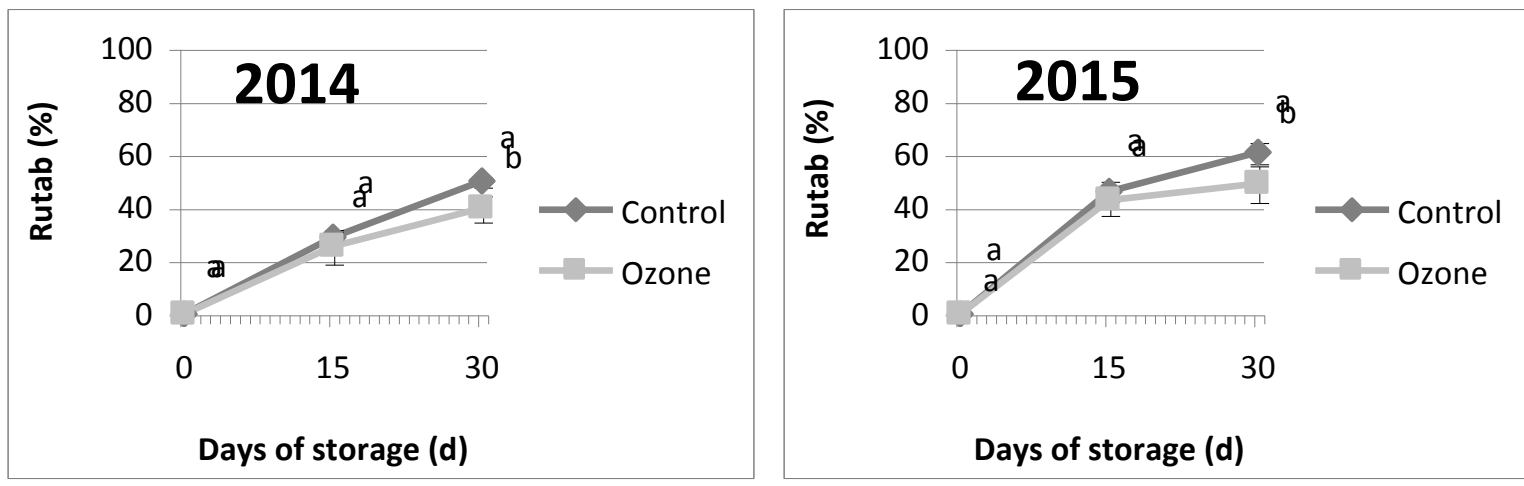

(c)

Fig.1. The effect of ozone exposure on weight loss (a), electrolyte leakage (b) and rutab percentage (c) of Zaghloul date fruits after 15 and 30 days of cold storage at $0 \pm 1^{\circ} \mathrm{C}$ in 2014 and 2015 seasons. Means followed by a different letter differ significantly at $P=0.05$ by L.S.D test.

\section{Fruit total soluble solids}

Total soluble solids of the fruits under storage were increased with the advancement of storage period irrespective of the treatments applied (Fig. 2a). At 15 days of cold storage, the TSS\% did not differ significantly between ozone treated fruits and nonozone treated ones. However, after 30 days of cold storage the TSS was kept at minimum level in ozone treated fruit in comparison to maximum TSS, recorded in the fruits stored at non-ozone treated ones (control). The results are comparable to those reported by Perez et al. (1999) on ozonation of strawberries who showed a decrease in the sugar content of the fruit from 19.9 to 8 $\mathrm{mg} / \mathrm{g}$ of fresh weight. In addition, Minas et al. (2012) also detected a decrease in soluble solids content in kiwifruits, stored in ozone enriched cold atmosphere.
However, Aguayo et al (2006) and Niakousari et al. (2010) did not observe any significant difference between the monosaccharide levels of ozonated tomato and those of the nonozonated samples. In addition, a linear increase in TSS content of non-ozone treated fruits occurred during 15 to 30 days of cold storage. The increase in TSS during storage may due to the breakdown of complex polymerse into simple substances by hydrolytic enzymes, which may be further metabolized during respiration. On the other hand, a slight increase in TSS during the same period was obtained in ozone treated fruits. Maintaining the TSS at lower level by ozone treatment may be due to slow rate of respiration and ripening processes (Zhang et al., 2011). 


\section{Titaratble acidity content}

Data of both years (2014 and 2015) indicated no significant difference between ozone and mom-ozone treated fruits in their acidity content after 15 and 30 days of cold storage ( Fig 2b). Consistent with the present results, the previous studied also suggested that ozone had no effect on acidity of the product in apples (Skog and Chau, 2001), kiwi (Barboni et al., 2010 and Minas et al., 2012), persimmon (Salvador et al., 2006), orange (Whangchai, 2010) and tangerine (Boonkorn et al., 2012). Artes-Hernandez et al. (2004) did not

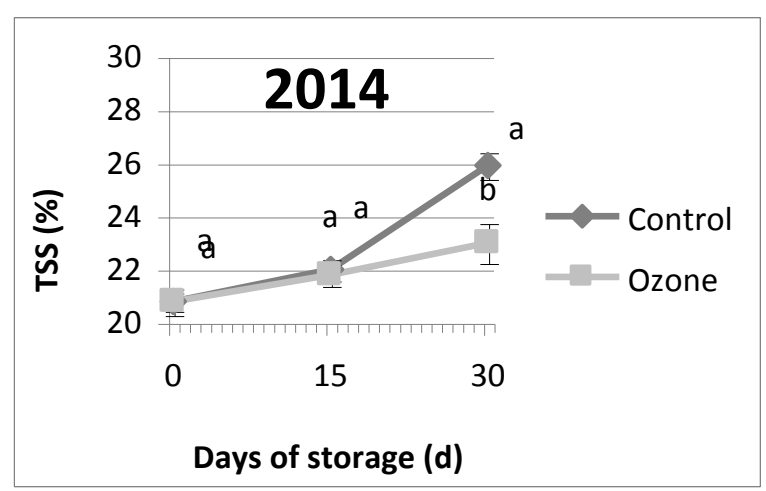

(a)
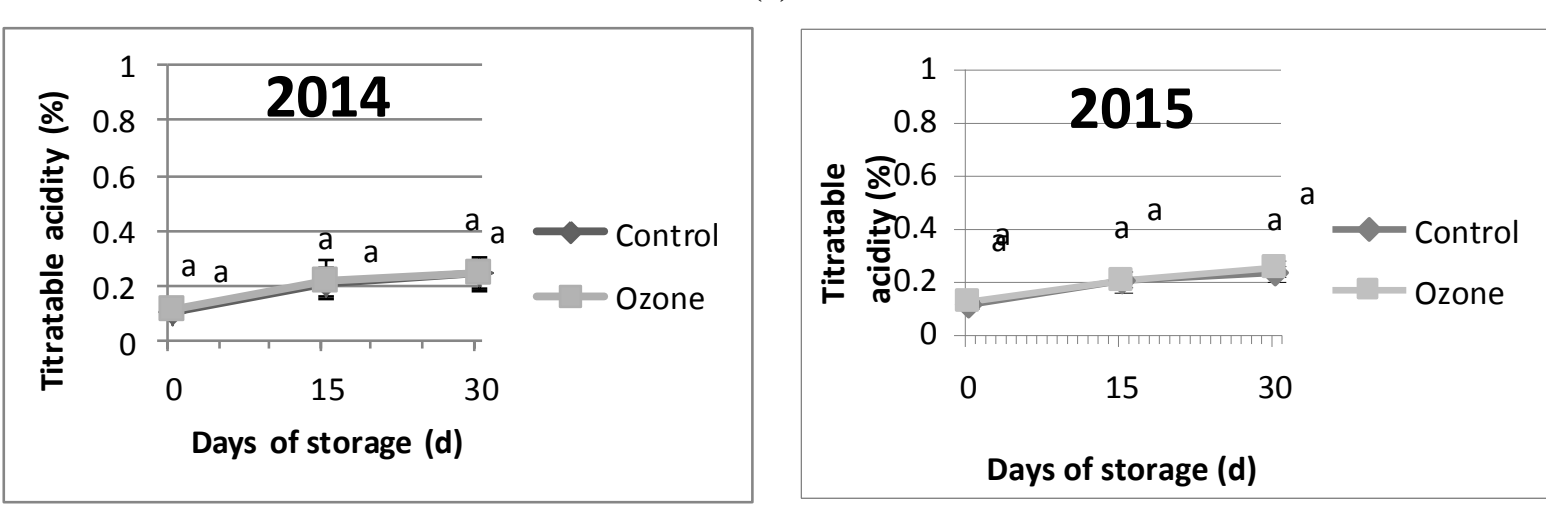

observe differences in acidity between ozone-exposed and control 'Autumn seedless' grapes; In contrast, Cayuela et al. (2009) found that 'Regina Victoria' grapes acidity significantly increased in samples continuously or intermittently exposed to ozone at 2 ppm during storage at $5^{\circ} \mathrm{C}$. In 'Cardinal' grapes exposure to ozone had no effect on produce acidity, whereas in continuously exposed grapes acidity increased. Interestingly, in 'Superior Seedless' grapes, produce acidity was reduced in response to ozone.

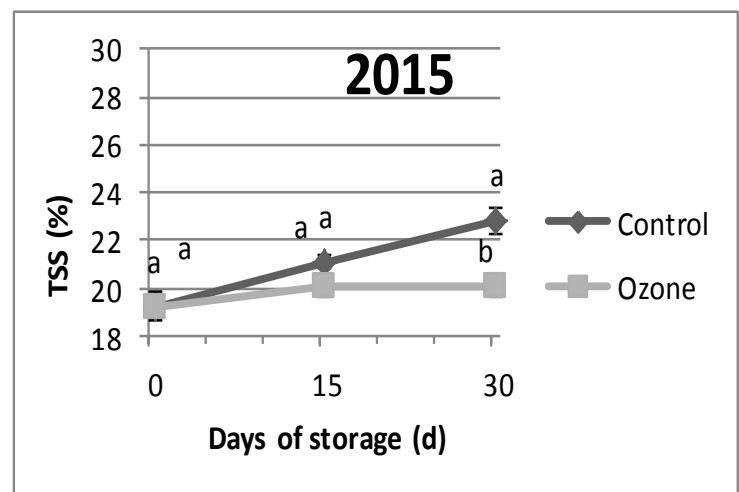

(b)

Fig.2. The effect of ozone exposure on TSS (a) and titratable acidity (b) of Zaghloul date fruits after 15 and 30 days of cold storage at $0 \pm 1^{\circ} \mathrm{C}$ in 2014 and 2015 seasons. Means followed by a different letter differ significantly at $P=0.05$ by L.S.D test.

\section{Ascorbic acid content}

Variations in ascorbic acid values during storage are shown in Fig. 3a. Ascorbic acid values decreased continuously during cold storage. On the handling day, ascorbic acid value of non-ozone treated fruits was 3.60 $\mathrm{mg} / 100 \mathrm{~g}$ fw, while after 15 and 30 days of cold storage was 1.39 and $1.20 \mathrm{mg} / 100 \mathrm{~g}$ fw. The concentration of ascorbic acid was significantly higher in ozone treated fruits than non-ozone treated ones. For example, in 2015 season, ascorbic acid values of control fruits after 15 and 30 days of cold storage were 2.0 and $1.8 \mathrm{mg} / 100 \mathrm{~g}$ fw, respectively while, the corresponding values for ozone treated fruits were 3.70 and $2.83 \mathrm{mg} / 100 \mathrm{~g}$ fw. This could be due to the activation of fruit defense system that produces a high level of ascorbic acid to neutralize the oxidative activity caused by ozone. These results confirm those obtained by Perez et al. (1999), where ozone treated strawberries showed an increase in the concentration of ascorbic acid from 0.07 to 0.14 $\mathrm{mg} / \mathrm{g}$. They related this increase in ascorbic acid to high oxidative capacity and ability of ozone to generate toxic molecular species, acting as a potent phytotoxic agent. They further suggested that the sugar may change to ascorbic acid in the ozonation process. It is reported by other investigators that in aqueous solutions it is likely that ozone may react with glucose to produce gluconic acid (Box, 2001). Moreover, the stimulating effect of oxidative stress on ascorbic acid level was also observed in pepper treated ozone (Alwi and Ali, 2015). They attributed this increase to activation of ROS scavenging 
genes as a fruit's second line of defense. This involves reduction of monodehydroascorbate (MDA) and dehydroascorbate (DHA) through ascorbate-glutathione cycle which involves enzymes such as dehydroascorbate reductase (DHAR) and monodehydroascorbate

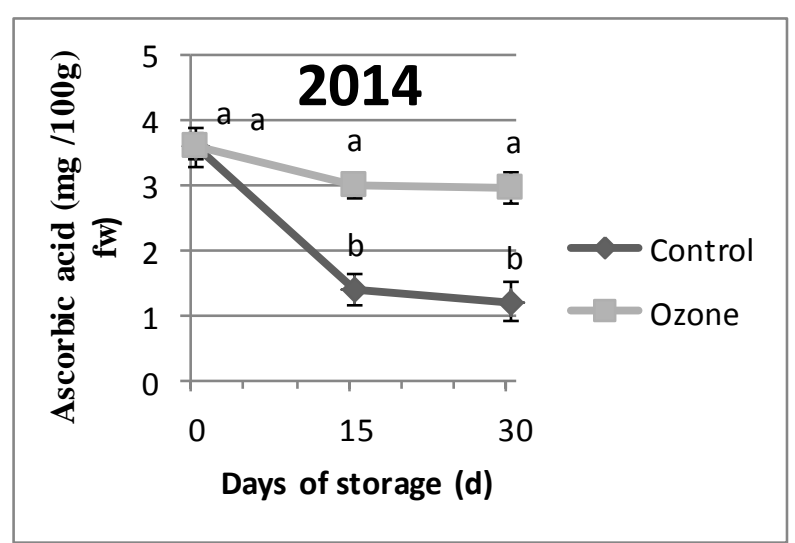

(a)

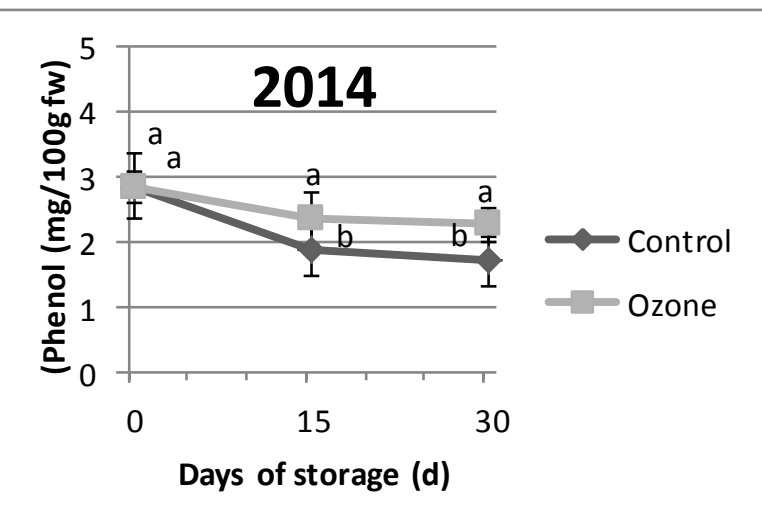

(b)

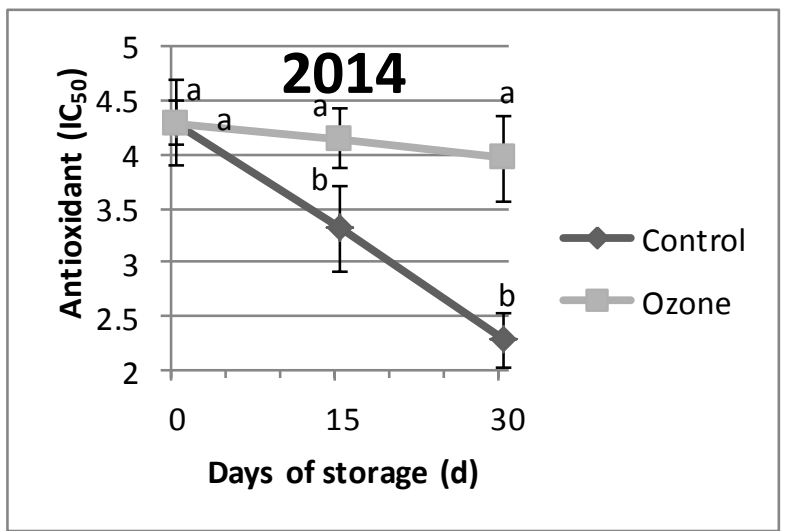

(c)

Fig.3. The effect of ozone exposure on ascorbic acid (a), total phenol content (b) and antioxidant activity (c) of Zaghloul date fruits after 15 and 30 days of cold storage at $0 \pm 1^{\circ} \mathrm{C}$ in 2014 and 2015 seasons. Means followed by a different letter differ significantly at $P=0.05$ by L.S.D test.

\section{Total phenolic content}

At the first 15 days of cold storage total phenol decreased slightly and maintain stable after 30 days in both ozone and non-ozone treated fruits (Fig. 3b). However, in both experimental years, the ozone treated fruits contained higher phenols than non-ozonated ones.

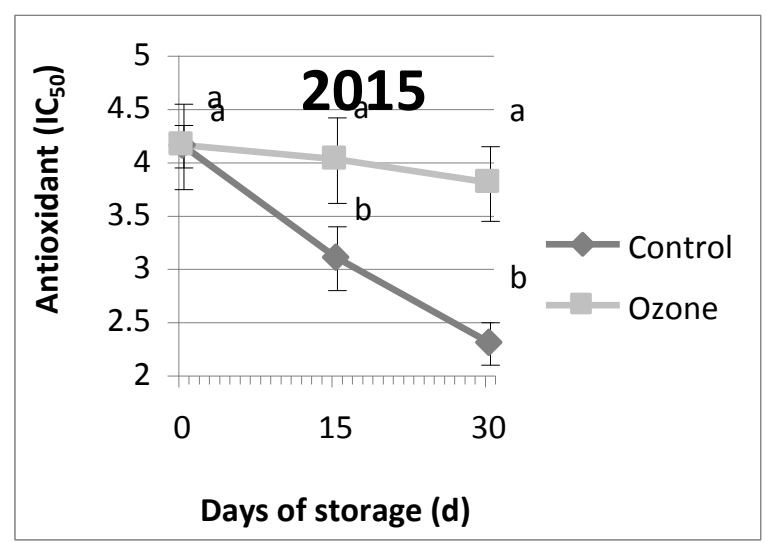

reductase (MDAR) (Forney, 2003). This increases the level of reduced ascorbate to neutralize oxidative action of ozone. Also, increase ascorbic acid content in the fruit, which increases value of the fruit in terms of vitamin content.
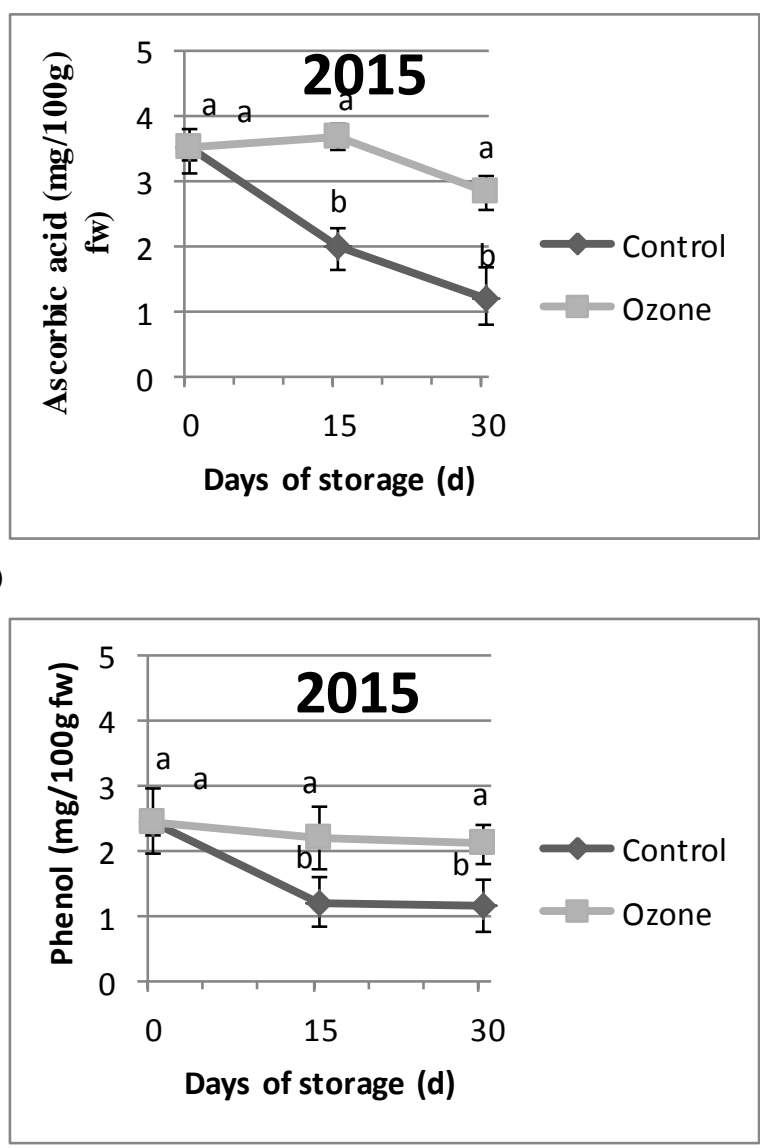

)

Similar results have been reported for banana and pineapple (Alothman et al. 2010), grapes (Cayuela et al. 2009) and kiwi (Minas et al. 2012). They all concluded that ozone treatment induced higher total phenolic contents. Besides, Ali et al. (2014) reported that higher increase in total phenolic content in response to ozone at 
1.5-5 ppm for $96 \mathrm{~h}$ in papaya when compared with control fruit in non-ozonated environment. This enhancement might be attributed to the role of ozone in excess oxidative stress and production of ROS, which then need to be scavenged by antioxidants, e.g. phenolic compounds. Moreover, Toivonen and Brummell (2008) demonstrated that the accumulation of phenolic by ozone is induced through increase in phenylalanine ammonialyase (PAL) activity or reduced polyphenol oxidase (PPO) and/or peroxidase (POD) activity, which are all involved in polyphenol biochemistry.

Antioxidant activity

Data presented in Fig. 3c indicated a significantly high antioxidant activity in ozone treated fruits in comparison with the non-ozone treated ones during 15 and 30 days of cold storage. Moreover, antioxidant activity slightly decreased in the ozone treated fruits starting at handling day and until 30 days storage compared with the non-ozonated treated ones, were sharp decrease in antioxidant activity was obtained with extending the storage period. Antioxidant activity measured was found to increase in ozone-exposed banana and pineapple (Alothman et al. 2010), kiwi (Minas et al. 2012) and papaya (Ali et al, 2014). Significant correlation between antioxidant and total phenol in date palm fruits has been established by many investigators (Biglari et al., 2008). It is established that the antioxidant activity of dates was due mainly to the presence of water-soluble compounds with potent free radical scavenging effects, including the phenolic compounds (mainly cinnamic acids) and flavonoids (Mansouri et al. 2005; Biglari et al. 2008) confirming that these compounds play important role in antioxidant activities (Kosanić et al., 2011).

\section{CONCLUSION}

According to the results obtained in the present study, ozone application at $150 \mathrm{ppb}$ ozone $\left(\mathrm{O}_{3}\right)$ would improve fruit storage life by inhibiting microbial growth and maintaining postharvest fruit quality of Zaghloul dates.

\section{Acknowledgment}

The author would like to thank Dr. Diaa O. ElAnsary, Precision Agricultural Laboratory, Department of Pomology, Faculty of Agriculture, El-Shatby, University of Alexandria, Alexandria, Egypt) for providing ozone generator unit (biofresh OZ80, UK) for this research .

\section{REFERENCES}

Abeles, F.B; P. Morgan and M.E. Saltveit (1992). Ethylene in Plant Biology, $2^{\text {nd }}$ ed. Academic Press, San Diego.

Aguayo, E.; V. H. Eacalona and F. Artes (2006). Effect of cyclic exposure to ozone gas on physicochemical, sensorial and microbial quality of whole and sliced tomatoes. Postharvest Biol. Technol., 39: 169-177.
Aleid, S. and S. H. Hamad (2014). Use of ozonated water for controlling microbial contamination of date palm fruits. Proceedings of the fifth international date palm conference. Abu Dhabi, UAE.

Ali, A.; M.K. Ong and C.F. Forney (2014). Effect of ozone pre-conditioning on quality and antioxidant capacity of papaya fruit during ambient storage. Food Chem., 142:19-26.

Alothman, M.; B. Kaur; A. Fazilah; R. Bhat and A. A. Karim (2010). Ozone-induced changes of antioxidant capacity of fresh-cut tropical fruits. Innov. Food Sci. Emerg. Technol., 11: 666-671.

Alwi, N. A. and A. Ali (2015). Dose-dependent effect of ozone fumigation on physiological characteristics, ascorbic acid content and disease development on Bell pepper (Capsicum annuum L.) during storage. Food Bioprocess Technol., 8: 558-566.

AOAC, (1995). Official Methods of Analysis, fifteenth ed. Association of Official Analytical Chemists, Washington, DC, USA.

Ao, C.; A. Li; A. A. Elzaawely; T.D. Xuan and S. Tawata (2008). Evaluation of antioxidant and antibacterial activities of Ficus microcarpa L, Fil. Extract. Food Control, 19: 940-948.

Artes-Hernandez, F.; E. Aguayo and F. Artes (2004). Alternative atmosphere treatments for keeping quality of 'Autumn seedless' table grapes during long-term cold storage. Postharvest Biol. Technol., 31:59-67.

Barboni, T.; M. Cannac and N. Chiaramonti (2010). Effect of cold storage and ozone treatment on physicochemical parameters, soluble sugars and organic acids in Actinidia deliciosa. Food Chem., 121:946-951.

Bell, C. H. (2000). Fumigation in the 21st century. Crop Protection, 19, 563e569.

Beuchat, L. R. and M. A. Cousin (2001). Yeasts and molds. In F. P. Downes, \& K. Ito (Eds.), Compendium of Methods for the Microbiological Examination of Foods (4 ${ }^{\text {th }}$ ed.). (pp. 209-215) Washington, DC: American Public Health Association (APHA).

Biglari F; A. F. Alkarkhi and A. M. Easa (2008) Antioxidant activity and phenolic content of various date palm (Phoenix dactylifera) fruits from Iran. Food Chem., 107:1636-1641.

Boonkorn , P. H. Gemma; S. Sugaya; S. Setha; J. Uthaibutra and K. Whangchai (2012). Impact of high-dose, short periods of ozone exposure on green mold and antioxidant enzyme activity of tangerine fruit. Postharvest Biol. Technol., 67:25-28.

Box, V. G. S. (2001). The role of lone pair interactions in the chemistry of the monosaccharides. The mechanisms of the oxidations of monosaccharides by bromine, chromium trioxide in acetic acid, and ozone. J. Mol. Struct., 569:167-178. 
Cayuela, J. A.; A.Vazquez; A. G. Perez and J. M. Garcia (2009). Control of table grapes postharvest decay by ozone treatment and resveratrol induction. Food Sci. Technol. Int., 15:495-502.

Cheng, R. and F. Hanning (1955). Phenolic compounds in potato tissue. Food Res., 20: 506-511.

EL-Saedy, R. M. ; D. O. El-Ansary; N. I. EL-Naggar and A. M. Hussein (2011). Postharvest Ozone and Hot Water Treatments Increase Storage Life of Kent Mango Fruits at Two Maturity Stages. Alexandria journal of Agricultural Research, 56, No. (1): $97-$ 108

FAO, 2009. Food and Agriculture Organization of the United Nations: DATE PALM PRODUCTS. http://www.fao.org/docrep/t0681E/t0681e03.htm.

FDA, 2009. Food Code - Poisonous or Toxic Materials. US Food and Drug Administration, PublicHealth.Service.http://www.fda.gov/Food/Foo dSafety/RetailFoodProtection/FoodCode/ucm05441 7.htm

Forney, C. F. (2003). Postharvest response of horticultural products to ozone. In M. Hodges

(Ed.), Postharvest Oxidative Stress in Horticultural Crops (pp. 13-53). Binghamton, NY, USA: Food Product Press ${ }^{\circledR}$.

Freitas-Silva, O. and A. Venancio (2010). Ozone applications to prevent and degrade mycotoxins: a review. Drug Metab. Rev., 42(4):612-620.

Hwang, E. S.; J. N. Cash and M. J. Zabik (2001). Postharvest treatments for the reduction of

mancozeb in fresh apples. Journal of Agricultural and Food Chemistry, 44: 3127-3132.

Khadre, M. A.; A. E. Yousef and J. G. Kim (2001). Microbiological aspects of ozone applications in food: a review. J. Food Sci., 66(9):1242-1252.

Komanapalli, I. R. and B. H. S. Lau (1996). Ozoneinduced damage of Escherichia coli K-12. Appl Microbiol. Biotechnol., 46(5-6): 610-614.

Kosanić, M.; B. Ranković and J.Vukojević (2011). Antioxidant properties some lichen species. J. Food Sci. Technol., 48(5):584-590.

Liew, C. L. and R. K. Prange (1994). Effect of ozone and storage-temperature on postharvest diseases and physiology of carrots (Daucus carota L.). J Am. Soc. Horti. Sci., 119(3):563-567.

Mansouri, A.; G. Embarek; E. Kokkalou and P. Kefalas (2005). Phenolic profile and antioxidant activity of the Algerian ripe date palm fruit (Phoenix dactylifera). Food Chem., 89:411-420.

Minas, I. S.; G.S. Karaoglanidis; G.A. Manganaris and M. Vasilakakis (2010). Effect of ozone application during cold storage of kiwifruit on the development of stern-end rot caused by Botrytis cinerea. Postharvest Biology and Technology, 58: 203-210.

Minas, I. S.; G. Tanou; M. Belghazi; D. Job; G.A. Manganaris; A. Molassiotis; M.Vasilakakis (2012). Physiological and proteomic approaches to address the active role of ozone in kiwifruit postharvest ripening. J. Exp. Bot., 63(7): 2449-2464.
Morton, R. D. (2001). Aerobic plate count. In F. P. Downes, \& K. Ito (Eds.), Compendium of Methods for the Microbiological Examination of Foods (4th ed.).(pp. 63e67) Washington, DC: American Public Health Association (APHA).

Najafi, M.B.H. and M. H. H. Khodaparast (2009). Efficacy of ozone to reduce microbial populations in date fruits. Food Control, 20(1):27-30.

Niakousari, M.; Z. Erjaee and Sh. Javadian (2010). Fumigation characteristics of ozone in postharvest treatment of Kabkab dates (Phoenix dactylifera L.) against selected insect infestation. Journal of Food Protection, 73 (4): 763-768.

Ozkan, R.; J.L. Smilanick and O. A. Karabulut (2011). Toxicity of ozone gas to conidia of Penicillium digitatum, Penicillium italicum, and Botrytis cinerea and control of gray mold on table grapes. Postharvest Biology and Technology, 60: 47-51.

Palou, L.; C. H. Crisosto; J.L. Smilanick; J.E. Adaskaveg and J.P. Zoffoli (2002). Effects of continuous $0.3 \mathrm{ppm}$ ozone exposure on decay development and physiological responses of peaches and table grapes in cold storage. Postharvest Biology and Technology, 24: 39-48.

Palou, L.; J. L. Smilanick; C. H. Crisosto; M. Mansour and P. Plaza (2003). Ozone gas penetration and control of the sporulation of Penicillium digitatum and Penicillium italicum within commercial packages of oranges during cold storage. Crop Protection, 22: 113-1134.

Parish, M. E.; L. R. Beuchat; T. V. Suslow; L. J. Harris; E. H. Garret; J. N. Farber (2003). Methods to reduce/eliminate pathogens from fresh and freshcut produce. Comprehensive Reviews in Food Science and Food Safety, 2, 161-173.

Perez, A.; C. Sanz; J. J. Rios; R. Olias and J. M. Olias (1999). Effect of ozone treatment on postharvest strawberry quality. J. Agric. Food Chem., 47:1652-1656.

Ranganna, S. (1979). Manual of Analysis of Fruit and Vegetable Products, second ed.Tata McGrawHill, New Delhi, pp. 634.

Rao, M.V.; J. R. Kozh; K. R. Davis (2000). Ozone: a tool for probing cell death in plants. Plant

Mol. Biol., 44:345-58.

Salvador, A.; I. Abad; L. Arnal and J. M. MartinezJavega (2006). Effect of ozone on postharvest quality of persimmon. J. Food Sci., 71:S443S446.

Sharma, R. R.; A. Demirci; L. R. Beuchat and W. F. Fett (2002). Inactivation of Escherichia coli O157:H7 on inoculated alfalfa seeds with ozonated water and heat treatment. Journal of Food Protection, 65: 447-451.

Skog, L.J. and C. L. Chu (2001). Effect of ozone on qualities of fruits and vegetables in cold storage. Can. J. Plant Sci., 81: 773-778.

Snedecor, G.W. and W.G. Cochran (1980). Statistical Methods, $7^{\text {th }}$ Edn. Ames: lowa State University press. 507pp. 
Toivonen, P.M.A and S. Stan (2004). The effect of washing on physicochemical changes in packaged, sliced green peppers. Int. J. Food Sci. Technol., 39(1):43-51.

Toivonen, P.M.A. and D. A. Brummell (2008). Biochemical bases of appearance and texture changes in fresh-cut fruit and vegetables. Postharvest Biol Technol 48:1-14 .

Whangchai, K.; K. Saengnil; C. Singkamanee; J. Uthaibutra (2010). Effect of electrolyzed oxidizing water and continuous ozone exposure on the control of Penicillium digitatum on tangerine cv. 'Sai Nam Pung' during storage. Crop Protection, 29: 386-389
Yaseen, T.; A. Ricelli; P. Albanese; I. Nicoletti; S. Essakhi and A.M. D’Onghia (2014). Influence of postharvest ozone treatment on decay, catalase, lipoxygenase activities, and anthocyanin content of 'Redglobe' table grapes. IOA-EA3G Conference, 1 (33):1-8.

Zhang, L.K.; Z. X. Lu; Z. F.Yu and X. Gao (2005). Preservation of fresh cut celery by treatment of ozonated water. Food Control, 16(3):279-283.

Zhang, X.; Z. Zhang; L. Wang; Z. Zhang; J. Li and C. Zhao (2011). Impact of ozone on quality of strawberry during cold storage. Front. Agric. China, 5(3): 356-360.

\section{تاثير المعاملة بالاوزون علي جودة ما بعد الحصاد والحالة الميكروبيولوجية لثمار البلح الزغلول هدي علي عبد المحسن خليل الاوزيل قسم الفاكهة ـ كلية الزراعة_ الثاطبي- جامعة الاسكندرية}

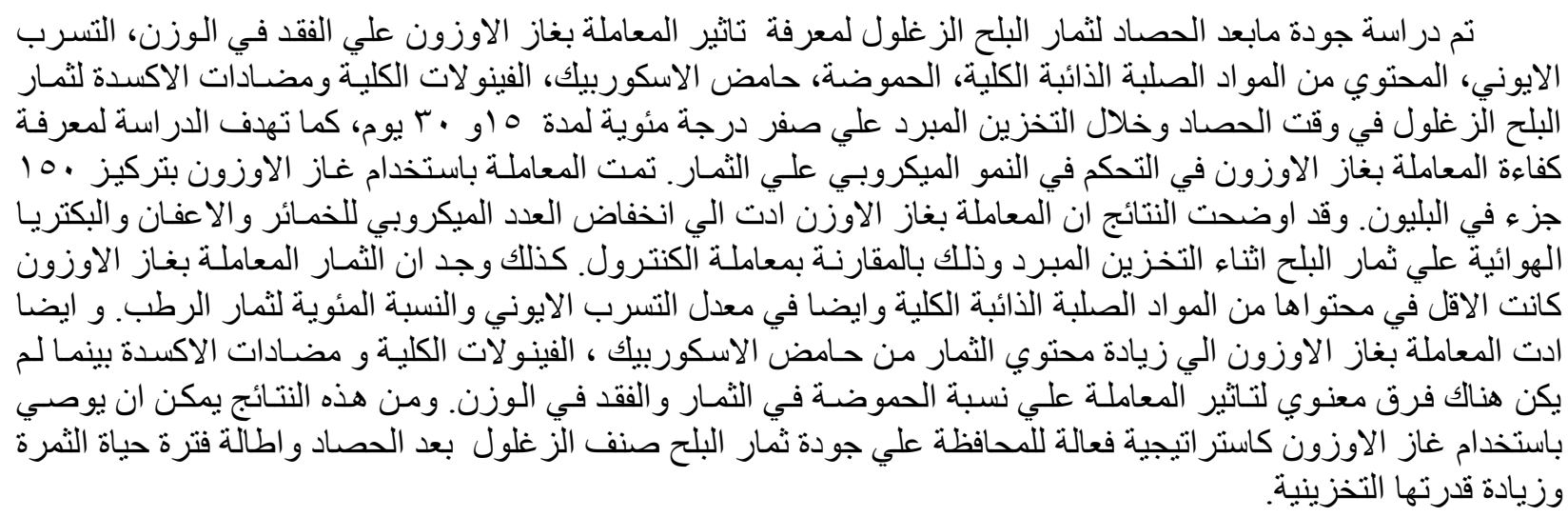

